Article

\title{
Degrees and Forms of Commercialization: Community-Managed Water Operators in Lamongan Regency, Indonesia
}

\author{
Mireia Tutusaus ${ }^{1, *}$, Risky Aditya Surya ${ }^{2}$ and Klaas Schwartz ${ }^{3, *}$ \\ 1 IHE Delft, Institute for Water Education, 2611 AX Delft, The Netherlands \\ 2 BPPSPAM (Badan Peningkatan Penyelenggaraan Sistem Penyediaan Air Minum), Jakarta 12170, Indonesia; \\ risky.as@bppspam.com \\ 3 Amsterdam Institute for Social Science Research, University of Amsterdam, \\ 1018 WV Amsterdam, The Netherlands \\ * Correspondence: m.tutusaus@vei.nl (M.T.); k.schwartz@un-ihe.org (K.S.)
}

Received: 31 May 2019; Accepted: 14 September 2019; Published: 23 September 2019

\begin{abstract}
Globally, the water services sector has adopted commercial principles since the 1980s and 1990s. Most of the reforms based on these principles have been introduced as part of broader neoliberal reforms in these countries. Often these reforms are portrayed as being homogenous and standardized, suggesting there is a shared understanding of commercialization. However, in recent years, scholars have explored the lack of universality of these principles when comparing the implementation of these reforms across settings. Across different countries significant differences in implementation and outcomes of commercialization can be identified. In much of this literature, emphasis is placed on the differences visible in the implementation of commercialization across different geographical areas. In this article, we contribute to this literature by questioning the universal application of the principles of commercialization even within the same geographical area and actor. Using the case of community-based organizations in Lamongan Regency, Indonesia, this paper elaborates on the multiple manifestations of commercialization when documenting the actual practices of water operators. We argue that, within even the operations of these water operators, commercial principles are indeed differently implemented from the original commercial model of water provisioning. The deviations from the model can be attributed to not only local conditions under which the water providers operate, but also reflect the interests of the implementing agency and its environment. The deviations from the model of commercialization lead to questions about the validity of this model as they re-interpret key principles of the model. Yet, we find that little of these divergences and re-interpretations are reported upon. As a result, these two models of commercialization, the one practiced by the water operator and the one endorsed by donors and sector organizations co-exist as separate, and equally valid, guidelines. We advocate for a richer vocabulary to describe or refer to different manifestations and interpretations of commercialization as this may lead to a more honest development of water services for all.
\end{abstract}

Keywords: water services; policy implementation; commercialization

\section{Introduction}

Despite the almost seemingly universal manifestation of neoliberal reforms in the water sector, the actual implementation of these neoliberal reforms may be less homogenous than some of the literature may suggest [1-3] Changes and adaptations to neoliberal principles during implementation of reforms bringing these principles in, have been documented and demonstrate that the actual processes through which neoliberal reforms unfold are quite diverse and in fact depend on the specific socio-economic 
and political context in which these very same reforms are implemented [1]. This perspective contests the idea of a global convergence of neoliberalization as a uniform package of reforms. Instead, what becomes apparent is that "there is no uniform template of neoliberal reform in the water sector and neoliberalizing transformations are not simply imposed from elsewhere as fixed templates" [3] That policy discourse may be different from what develops in the ground echoes work on policy implementation studies. Studies focusing on policy implementation view the implementation phase as an integral part of the policy process, where policy is thus still being made [4,5]. As such, local adaptations of policies and policy models are considered as an informative and valid part of the policy. By studying implementation like this, they take as departing point that changes between policy at design and at implementation will always, most likely, occur. Furthermore, differences between design and implementation are not an indication of faulty implementation, but rather are viewed as expected and necessary adjustments that allow a policy to be molded to fit a particular context [6,7]. With these perspectives in mind, we expect that all reforms to the water services sector through the introduction of commercial principles will unfold into a unique implementation, characterized by a different form or degree of commercialization. The possibility for unique interpretations of neoliberal principles across different countries, or specifically the commercialization of water services, has been documented (see [3]). Acknowledging that policy ideals are transformed during implementation necessarily raises questions about the universal validity of principles as brought in by neoliberal reforms. In this article, we elaborate on the existing documentation of these unique interpretations at implementation by investigating Community-Based Organizations (CBOs) in Indonesia. In studying $\mathrm{CBO}$ s in small towns and rural areas, we assume that the introduction of commercial principles in the provision of services will likely exhibit certain adaptations from the commercial model that was originally envisioned during policy design. In the analysis of our cases we argue that these adaptations are not only possible discrepancies in neoliberal reforms across different geographical locations (countries), but that such different manifestations of commercialization are also observable within a single actor, in our case the $\mathrm{CBO}$. The adaptations to the policy model of commercialization implemented by the water provider not only diverge from the original model, but, at times, even contradict the model. Despite the apparent contradictions, the ideal model remains unchallenged offering little grounds for rethinking the validity of the model, and its underlying principles.

In order to develop this argument, we first present the policy ideal of commercialization as promoted by international donors and endorsed by the Indonesian government to provide water to small towns and villages in rural areas of the country through commercialized CBOs. Subsequently, we elaborate on how these CBOs implement commercialization in daily practice and highlight the deviations between the practice of these CBOs and the policy ideal. We do this by exploring the cases of eight CBOs in the Lamongan Regency in the island of Java in Indonesia. The original research objective was to reveal what factors had enabled the CBOs in the Lamongan Regency to apparently operate as commercially viable businesses able to expand services over time. What this research revealed, however, was that a much richer interpretation of commercial viability is required to grasp and place the practices and operations of these water providers.

\section{Commercialization of Water Services}

Although the 'water privatization decade' only lasted from 1993 to 2003 [8] it had a lasting impact on the water services sector. By 2003, when the momentum for private sector involvement had subsided, the International Financing Institutes such as the World Bank opted to re-engage with public water utilities after having promoted the involvement of private operators in water service provision for over a decade. This re-engagement with public water utilities did not mean, however, a return to public water operators as they operated before the privatization decade. Rather, in this new engagement with (public) water utilities, these providers were expected to operate on the basis of commercial principles, much like private water operators were thought to operate. This shift was grounded in the belief that "(w)ell-run public utilities of the developing world have much in common with efficient private 
providers" $[9,10]$. The introduction of private sector 'discipline' in public water utilities increasingly became a model for reform that was considered both effective and less controversial than models of privatization in which private water operators would take over the provision of services [11-13].

This adoption of private sector principles and practices by public water utilities is generally referred to as 'commercialization'. Commercialization refers to the "reworking of the management institutions (rules, norms and customs), and entails the introduction of markets as allocation mechanisms, market simulating decision making techniques and the displacement of Keynesian-welfarist by neo-liberal principles in policymaking" [1]. In theory, commercialization does not necessarily replace the type of organization providing services, as would happen with privatization, but rather it refers to "a change in the way the organization operates and is managed" [14].

Despite some minor differences in the definitions, there is a considerable agreement on the main principles of commercialization [14-19]. The essence of commercialization revolves around creating the conditions under which a utility is able to operate independently from any third party. This is achieved by 1) establishing autonomous organizations that are able to operate at arms-length of the government and are, therefore, removed from the political influence of these establishments; and 2) achieving (full) cost-recovery which would allow these utilities to operate without being dependent on other bodies for subsidies to cover their operational and investment costs. These principles, initially introduced to turn around the less favorable conditions under which public utilities operated, rapidly expanded as general guiding principles for all other types of service providers. This also included the principles under which community-based organizations were to operate.

\section{Community-Based Organizations as (Commercial) Water Providers}

In the declaration of the New Delhi Principles [20] and the Dublin Principles [21], community-based management and participation were explicitly endorsed as important elements to continue to expand water services to all. Following this event, a workshop was organized by IRC in the Netherlands in 1993 to discuss the role of community management for water supply. The Occasional Paper that was produced as an output of that workshop highlights three reasons to promote community-based management. The first two reasons concern improvements in reliability and sustainability of services and the stimulus provided to community development. The third reason simply states: "It works!" [22].

Although critical notes on community participation long proceed both the New Delhi and Dublin declarations and the IRC workshop [23], the enthusiasm and optimism displayed in the workshop illustrate that community management, in the early 1990s, had become the main management model for rural water supply [24,25]. Despite the popularity of the model, its underlying principles of community cohesion, voluntarism and participation have also been described as being more 'idealistic than practical' [26-28]. Specifically, the voluntary basis sustaining the CBO has been identified as putting a 'high risk' on the sustainability of the system [29,30]. The policy response to these challenges has been to transform CBOs into more 'professional' organizations in which they abandon their 'voluntary approach' [25,27]. In the late 1990s, during the privatization decade, the demand responsive approach (DRA) was added as a complement to the community management model. Similarly to the turn that public water utilities were requested to make, the DRA is closely linked to a gradual transformation of seeing water as an economic good, which necessary requires the introduction of "management practices" centered around "careful attention to consumer demand" [31].

Community management and DRA proved to be an attractive combination of principles. It helped to both address the community-centered management, while incorporating a stronger emphasis on efficiency and effectiveness of operations. This framework envisions a reduced involvement of government bodies and argues that community members, being the end-beneficiaries of the water supply system, will have strong incentives to efficiently manage the water supply system as the community would not only be involved in the design and running of the system but would also bear the (full) cost for service delivery [29]. Whaley and Cleaver [32] suggest that "the implicit appeal of the (community-based management) concept for key development players (international 
donors, development organizations, and governments) is that it allows them to highlight a concern for sustainability whilst at the same time distancing themselves from much of the responsibility of delivering it" [32].

Despite the enthusiasm around community-based organizations running water systems in rural areas, only a portion (60-70\% in 2012) of rural water supply systems in developing countries remain operational [25]. The "sustainability of rural water supply projects, and of the benefits they deliver, is now one of the overriding concerns of the sector" [33]. As a result of these sustainability concerns, the emphasis on efficiency and commercial sustainability of CBOs is increasingly prioritized in rural water supply schemes. The focus on more professional and commercially sustainable CBOs is currently emphasized by the World Bank [34], which strongly promotes the idea of supporting community-based organizations that operate as autonomous entities and on the basis of full-cost recovery.

\section{Community-Based Organizations in Lamongan Regency, Indonesia}

The eight CBOs that were studied for this article were selected as these organizations are presented (inter)nationally as examples of commercially sustainable water service providers [35]. In other regions in Indonesia similar commercially-oriented community-based organizations funded by donor agencies had failed to sustain the provision of services upon completion of the project period. The selection of the eight cases was based on a set of criteria that reflect the financial viability and a certain degree of 'professionalization' of these organizations [35]. The case studies selected were able to expand services in scattered rural areas within the administrative boundaries of the Regency and were providing piped water to three to five times more households than the local water utility [36]. Moreover, they were able to access commercial financing and were currently servicing debt [36]. Data collection was carried from October 2016 to February 2017. Semi-structured interviews were held with leaders and volunteers of the CBOs (18 interviews). In addition, other relevant actors to the development of CBOs in the region were interviewed such as: CBOs Association (3), formal water utility (1), village chiefs (2), local and provincial government (5), and international donor agencies (5).

\section{Community-Based Organizations in Lamongan Regency, Indonesia}

The institutional framework governing water services provision in Indonesia is stipulated in Law 7/2004 on Water Resources and the Government Regulation 16/2005 on Water Supply System Development. According to these regulations the authority for water services development and delivery rests with the local government. Local government-owned public enterprises known as Perusahaan Daerah Air Minum (PDAMs) are responsible for developing and delivering water services. These PDAMs have a status of parastatal enterprises and are originally envisioned and established to operate on the basis of (full) cost recovery and, preferably, to contribute to the budget of the local government [33,37]. In the event that the PDAMs are not able to provide services of sufficient quality and quantity in its service area, the legal framework provides the possibility to engage other legal entities to provide services. As a result, there are three possible service provision models in small towns in Indonesia: services through a PDAM, services through a CBO or services provided through partnerships of the PDAM and CBOs [38]. In practice, the development of water supply systems for rural areas are delegated to $\mathrm{CBOs}$ and mainly funded by external aid agencies such as the World Bank and Australian Aid (AusAid).

In order to facilitate donor funding for the development of water infrastructure in rural areas, the government of Indonesia established the National Policy on Community Based Water Supply and Sanitation Services [38]. That resulted in policy 18/PRT/M/2007, issued by the Ministry of Public Works to guide the implementation of Law 7/2004 allowing for the establishment of organizations such as HIPPAMs. This policy largely follows the international trends on community managed water supply systems and was largely developed at the request of international donor agencies. The Policy notes assistance of the World Bank's Water and Sanitation Program (WSP-EAP) and the Australian Government's AusAID [38]. At the same time, the approach to have CBOs 
operate on a commercially-viable basis was well received by the Indonesian government as it was viewed as a way of reducing the financial burden of financially-strapped local governments [39]. The possibility of delegating water supply services to community-based organizations has led to a surge in community-based water provisioning in Indonesia. Estimates of the number of CBOs that operate in the Indonesian water services sector vary from around 13,000 CBOs [39] to "tens of thousands" [40]. The World Bank alone has developed 9,000 rural water supply schemes in Indonesia between 1990 and 2010 (WSP, 2011). According to the policy, CBOs in Indonesia are governed by the following principles $[38,41]$ :

- Water service as an economic good-The policy highlights a need to change "existing public perceptions" that water "has no economic value". By increasing "awareness and understanding of water's status of an economic good, overall practices of water use will improve, leading to a reduction in exploitation, and increased efficiency in use and a greater 'willingness to sacrifice' to obtain water".

- Demand-Responsive Approach-This approach is emphasized as it "places the community in the role of decision-maker in the selection, financing, and management of the (water supply and environmental sanitation) system".

- The Government as Facilitator-The government's role, particularly at the municipal and district level, is seen as providing technical and non-technical advisory services, with an aim to empower the community.

- The Cost-Recovery Principle-The policy highlights that, in light of the insufficient government funds available for water supply, future development and management of water supply and environmental sanitation infrastructure should be "based on the principle of cost recovery, meaning that all financial components of development (such as budget planning, physical construction, O\&M, and depreciation) have to be considered and accounted for". The principle of cost-recovery is forwarded as crucial in order to "ensure sustainability".

\section{The Introduction of Commercial CBOs in Lamongan Regency}

The initial approach of the World Bank to extend services through CBO management in the 1980s focused on infrastructural development and building technical capacities of service providers (WB1-Interview November 2016). In the 1990s, with a renewed emphasis on 'institutions and incentive structures', a second generation of World Bank sponsored CBO projects were implemented in Indonesia. In Lamongan Regency the Water and Sanitation Program (WSP) Indonesia, with the collaboration of the Indonesian Infrastructure Initiative (INDII-AUSAID), launched a program to develop CBOs (locally referred to as HIPPAMs-Himpuman Penduduk Pemakai Air Minum dan Sanitasi) resulting in more than 250 small scale systems in the Regency. These water systems service approximately 85,000 household connections, which provide water to an estimated 500,000 people. In Lamongan Regency, the water supply service landscape is dominated by CBOs, which cover between $70 \%-80 \%$ of the total population [41] Despite the efforts of central, regional and local governments to develop water services through local government-owned PDAMs, the PDAM in Lamongan Regency only serves 15,000 household connections (approximately 75,000 people).

The projects under which the HIPPAMs were set up provided for the initial investment covering the construction of the water systems. This included the borehole or surface water installation, pumps and the construction of one elevated reservoir tank. All costs related to network extensions and systems improvements (i.e., additional pumps or reservoirs) were to be developed and are currently fully-funded by the HIPPAMs themselves with only sporadic assistance from the HIPPAM's Association. The Association of HIPPAMs was established in the post-construction era of the WSLIC project (World Bank) in 2004. This Association provides services to the HIPPAMs. HIPPAMs requesting a service or training need to pay for this service. In order to foster the likelihood of the HIPPAMs to achieve 'long term sustainability' the projects provided training on financial management and reporting, assistance in the development of technical and financial proposals, and training on operations and maintenance 
of the water systems. In addition, $\mathrm{CBO}$ s were encouraged to strive for financial sustainability as they would be 'rewarded' with a performance grant (repayment of half of the loans) upon meeting agreed performance indicators [40]. The role of the local government was limited to creating 'enabling conditions'. However, despite the project envisioning local governments to play a facilitative role in the operation of the individual HIPPAMs, in practice the local government adopted a passive approach and did not offer any political, technical or financial support to the HIPPAMs. While the HIPPAMs report to the community, they are not formally accountable to the final user and the role of the user is limited to providing advice to the management of the HIPPAM (Table 1). The organizational structure of a HIPPAM is generally quite simple. A typical HIPPAM consists of a committee formed by 6-10 persons (Table 2). In addition to this remunerated staff, operational works on the water system is done by volunteers from the community.

Table 1. Overview of responsibilities.

\begin{tabular}{cccc}
\hline HIPPAMs & Community & Donor & Local Government \\
\hline $\begin{array}{c}\text { Responsible for } \\
\text { operations and } \\
\begin{array}{c}\text { maintenance, collection } \\
\text { of revenues and } \\
\text { expansion of network }\end{array}\end{array}$ & $\begin{array}{c}\text { Informed about tariff } \\
\text { design and other } \\
\text { HIPPAM related changes. } \\
\text { Not required to be } \\
\text { formally consulted. }\end{array}$ & $\begin{array}{c}\text { Funding of basic } \\
\text { infrastructure and } \\
\text { support through } \\
\text { trainings at the } \\
\text { beginning of the project. }\end{array}$ & $\begin{array}{c}\text { Facilitating agent. } \\
\text { In practice, far removed } \\
\text { from directly intervening } \\
\text { in the operations of the } \\
\text { HIPPAMs }\end{array}$ \\
\hline
\end{tabular}

Each HIPPAM can establish its own water tariff depending on the costs they deem necessary to recover (i.e., servicing debts, account for asset depreciation, operations and maintenance) and the ability to pay of their users. The tariffs are presented to the Village Chief and users. Although neither the Village Chief nor the users are able to approve or veto the proposed tariffs, the management of the HIPPAMs usually seeks to reach a consensus and understanding with the community regarding the tariff. The HIPPAMs are characterized by relatively high billing and collection rates $(80 \%-98 \%)$ and relatively high profit margins. Depending on the HIPPAM, profits ranged from $15 \%$ up to $57 \%$. The HIPPAMs can also be requested to pay a contribution fee to the community for the exploitation of the water resource. Generally, this is expressed as a percentage of the total revenue (usually about 3\%).

Table 2. Overview of HIPPAMs performance.

\begin{tabular}{|c|c|c|c|c|c|c|c|c|}
\hline 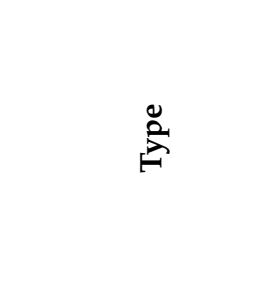 & 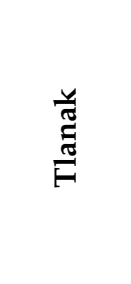 & 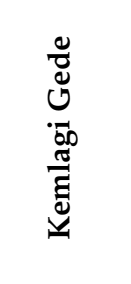 & 峁 & 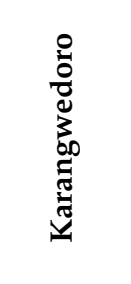 & 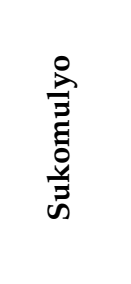 & च̃ & 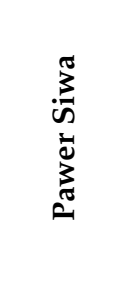 & 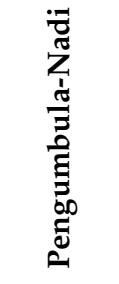 \\
\hline Tariff (IDR/m3) & 1300 & 1000 & 750 & 1000 & 2000 & 1300 & 2000 & 2000 \\
\hline $\begin{array}{l}\text { Billing collection } \\
\text { rate }(\%)\end{array}$ & 95 & 95 & 80 & 95 & 80 & 90 & 85 & 98 \\
\hline $\begin{array}{l}\text { Gross Profit (IDR } \\
\text { million/month) }\end{array}$ & 11.55 & 6 & 6 & 5 & 2 & 2 & 3.5 & 4 \\
\hline $\begin{array}{l}\text { Contribution to } \\
\text { Village }\end{array}$ & Yes & Yes & Yes & Yes & Yes & Yes & Yes & Yes \\
\hline Employees & 6 & 9 & 10 & 9 & 9 & 8 & 8 & 6 \\
\hline $\begin{array}{l}\text { Average Personnel } \\
\text { Cost (IDR) }\end{array}$ & 616,667 & 166,667 & 210,000 & 205,556 & 438,889 & 375,000 & 337,500 & 250,000 \\
\hline Growth Rate(\%) & 275 & 59 & 152 & 86 & 330 & 53 & 132 & 31 \\
\hline
\end{tabular}


There are several factors in the bio-physical and institutional context in which HIPPAMs operate that have been favorable to the development of these operators. One such factor is the limited availability of alternative sources of water. Lamongan Regency is located in an area where easy access to clean water is limited. The quality of the water from surface water bodies neighboring these settlements and shallow groundwater wells is considered to be poor. Moreover, coverage of the public water utility is limited, particularly in the more rural areas where the HIPPAMs operate. The lack of services or alternative sources of water of quality has prompted the appearance of private (informal) water vendors. These operators provide water and are seen as the only other alternative to access water, in addition to the services offered by the HIPPAMs. The private water vendors offer water at IDR 2000/jerry can (20 litre) or IDR 100,000/m³ ( $€ 1$ = IDR 16,888 (26 July, 2018); Head HIPPAM Pawer Siwa Village- Interview November 2016)) The average water tariff of the HIPPAMs ranged from IDR $750 / \mathrm{m}^{3}$ to IDR 2000/ $\mathrm{m}^{3}$ (Table 2). This tariff is 50 to 133 times lower (depending on the HIPPAM) than the prices charged by informal vendors. As a matter of fact, the tariff of the HIPPAMs is even lower than the PDAM tariff of IDR 2700/ $\mathrm{m}^{3}$. The HIPPAMs in Lamongan Regency provide water services at a tariff that is attractive to consumers and, in conjunction with limited access to alternative sources of good quality, results in a relatively high demand for HIPPAM services.

Two characteristics of the population being served by the HIPPAMs are important in terms of securing revenues. The first development is that Lamongan Regency has experienced a higher than average economic growth over the past years. This has led to an improved household average income (Statistics Bureau, 2015). This has facilitated the introduction of paid water services in these villages. At the same time, the percentage of consumers that are classified as belonging to the lowest-income bracket is between $50 \%-60 \%$ of the households [40].This dual development of increasing disposable income whilst remaining in the lowest-income bracket has meant that, given the absence of acceptable alternatives, consumers have a preference for the relatively low tariffs for HIPPAM water, whilst the ability to pay for the water that is delivered by the HIPPAMs has increased.

\section{Deviations from the Commercial Ideal}

The HIPPAMs in Lamongan were established with the idea that they would function as commercial entities. However, the commercial principles that were instilled through the donor-funded project at their establishment have evolved considerably as a result of the day-to-day operational practices of the HIPPAM.

\subsection{Alternatives to Sanctions}

During the initial project implementation phase the eight CBOs were trained by either World Bank or AusAid consultants on financial management. In addition to the practical topics of reporting, these trainings placed specific emphasis on punishment and sanctions in case consumers were not paying their water bills. Focus was dedicated to the timely issuing of water bills. Consumers were to be cut off from the service in case of delayed payment. However, in the tightly-knit communities in Lamongan Regency, these measures of disconnection proved difficult to implement (Secretary HIPPAM Geger Village- Interview December 2016). Most HIPPAM leaders considered disconnection measures "difficult and not suitable" in the context of village communities as many of the village residents are related to one another through relationships of employment or kin (Head HIPPAM Karangwedero Village- Interview December 2016). This does not mean that HIPPAMs disregarded the collection of revenues. Instead of imposing sanctions for non-payment, the HIPPAMs opted to embed the payment of water services in already existing and well-established social institutions, such as the local village committee or the community mosque. By entrenching the payment of water services in the existing social institutions of the village, most consumers not only feel obliged to pay, they also tend to pay on time. For example, when the request of paying for water services comes from the village chief who also represents the HIPPAM "consumers tend to be afraid not to pay" (Treasury/Finance HIPPAM Geger Village- Interview December 2016). One of the CBOs studied appointed the leader of the local 
mosque, a highly respected person in the community, as the Head of the HIPPAM. In another case, the Head of the HIPPAM was a village elder who enjoyed considerable respect within the village. As explained by one of the consumers: "We trust the CBO leader because of his active contribution to the village's development". The presence of village leaders in the CBOs appears to generate a sense of trust of consumers allowing for operational and financial decisions to be readily accepted. "The Head (of the $(B O)$ is usually a person trusted by the community and they have a good ability to communicate with the community including the delivery of HIPPAM's 'message'" (Head HIPPAM Pengumbulanadi Village interview November 2016).

\subsection{Reducing Costs}

Although securing a steady revenue stream is important, the provider also needs to ensure that this stream of income can actually cover the costs it faces if the provider is to be commercially viable. An important cost impacting the financial performance of HIPPAMs are personnel-related costs. In the case of the eight HIPPAMS studied in Lamognan, however, the average monthly cost for staff is very low. The average monthly salary ranged from less than IDR 200.000 to about IDR 600.000. In contrast, the minimum monthly salary, set by the Lamongan Regency Government, stands at IDR 1.7 million. Due to its low average salary, the personnel cost of HIPPAM only consumed about $11 \%$ to $30 \%$ of total revenues (Figure 1). In fact, the percentage of personnel costs as part of the total cost structure of any of the HIPPAMs studied is lower than average for this type and size of systems. In comparison, a World Bank [34] study analyzing the aggregation of services in small towns, suggests that staff costs often make up $60 \%$ of the costs for small-scale water providers. Even large scale water utilities, which are able to reap economies of scale, often have levels of personal-related costs, which are in the vicinity of $30 \%-35 \%$ [13].
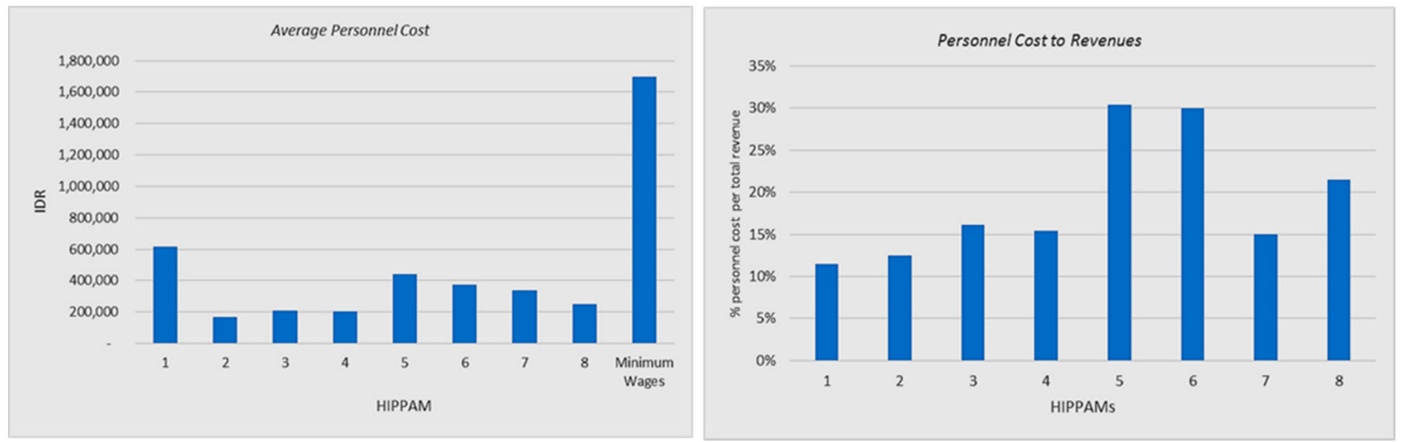

Figure 1. Personnel Cost and Personnel Cost as a Percentage of Revenues [36]

The low cost of labor-staff salaries-achieved by the HIPPAMs in Lamongan is strongly linked to the CBO's embeddedness within existing social institutions in the village. As highlighted earlier, the organizational structure of the $\mathrm{CBO}$ is kept lean and is mostly staffed by people that have another primary source of income. These community members do not see the HIPPAM as their primary source of income for their household. As one HIPPAM leader explained "the salary I earn from my profession as teacher has been sufficient to finance my family life, therefore I am not looking for money here in the HIPPAM" (Head HIPPAM Tlanak Village -Interview November 2016). Rather, for most of the members of these committees their commitment to the functioning of the HIPPAM is a contribution to the development of their communities or it reverts positively in other community-but not water related-aspects. For some individuals the incentive to work for the HIPPAM committee lays in the pride and prestige this position brings among the village community rather than providing direct monetary benefits. The trust and power entrusted in members of the committee creates opportunities for these individual members to later on gain new trusted positions in the community. One member of a HIPPAM committee explained how the position he held in the HIPPAM helped him run for the office of Village Chief, ultimately defeating the incumbent candidate (HIPPAM Pawer Siwa Village- 
Interview November 2016). In taking up these positions the work for and dedication to the HIPPAM is taken very seriously. As one committee member jokingly said: "I work as an education supervisor for a pre-school. However colleagues labelled me as 'water supervisor' because I often prioritize the HIPPAM" (Head HIPPAM Tlanak Village- Interview November 2016). The phenomenon of volunteer-based labor is often seen as barrier to professionalization and standing in the way of commercialization (see [34]). Volunteers would lack the technical and managerial capacity, as well as motivation, to operate the water systems [25]. However, the HIPPAMs in Lamongan Regency show that volunteerism is not necessarily synonymous with poor administrative and technical skills or lack of professional ethos. In the case of the HIPPAMs in Lamongan, sourcing voluntary labor from community members has not negatively impacted the performance of the utility, and has contributed to a reduction of the costs of the HIPPAM.

HIPPAMs have also explored other venues to continue reducing their operational expenses. Given that the HIPPAMs mainly exploit groundwater resources, the cost associated to energy consumption for pumping is relatively large. Initially, when the HIPPAMs were first established they were charged the electricity tariff for industrial use due to their estimated (and actual) consumption of over $3.5000 \mathrm{Kwh} / \mathrm{month}$. With the help of village leaders and the local government, the HIPPAM committees negotiated a social tariff with the electricity company (PLN). This was possible as "there is no rule that categorized HIPPAM as industry, so based on the nature of the HIPPAM we thought we can get social tariff for the electricity" (Trustee HIPPAMS Banyu Urip Association-Interview November 2016). Such a social tariff translates into a $40 \%$ reduction of total electricity costs for the HIPPAMs (Head HIPPAM Kemlagi Gede Village- Interview November 2016).

HIPPAMs are currently only regulated by INGUB 1985, which is the Governor Instruction of 1985. This regulation recognizes the possibility for organizations such as HIPPAMs to provide water services in rural areas. However, the role HIPPAMs play in the provision of services in the Lamongan Rgency is not currently reflected or fully acknowledged by local government (Head of Water Supply Section-Ministry of Public Works- Interview November 2016). As a result, most of the operational work of these organizations remains not regulated in detail. This 'lack' of regulation provides the HIPPAMS considerable room for maneuver. For example, this allowed HIPPAMs to negotiate their status for electricity tariff. This vague oversight also means that HIPPAMs are not obliged by any law to comply with technical standards and their water quality is not controlled. This, where considered to the advantage of the HIPPAMs is seized accordingly. The lack of regulation allows the HIPPAMs in Lamongan to offer cheaper services as they operate a less complex technological water supply system. In case of obligatory compliance to water quality standards the operational costs would increase and it is highly likely that HIPPAMs would have to increase their tariffs. For the moment, the local government does not attempt to readdress this situation. A local government officer explains that "we understand that we cannot force them to comply with the water quality standard, therefore we just 'close our eyes' when it comes to this issue" (Head HIPPAM Kemlagi Gede Village- November 2016). Needless to say, the lax regulation can also work against the HIPPAM as their status as water provider is largely unprotected. This is illustrated in cases where conflicts between HIPPAMs and PDAMS occurred. In these conflicts the local government usually sided with the PDAMs. For example, the service area of the HIPPAM in Sukomulyo conflicted and overlapped with the service area expansion of the local PDAM. The rights of the PDAM, which are owned by the local government, outweighed those of the HIPPAM. Such conflicts, can result in a significant decline in revenues for the HIPPAM.).

\section{Discussion}

\section{Between the Ideal and the Practice}

In order to make CBOs commercially viable, recent policy-oriented literature insists that " $(\mathrm{p})$ rofessionalization of community management with policy embedding, adequate legal frameworks and a move away from voluntarism" is the key building block for improving rural water services delivery. 
The ideal CBO appears to be one where a "water system is operated by an authorized business-like organization with a community basis either taking responsibility for service provision in a professional way or outsourcing this to other entities" [42]. Emphasis is thus placed on professionalism and the business-like nature of the $\mathrm{CBO}$, which allows these organizations to operate as (political and financial) autonomous entities. In looking at CBOs in Indonesia Al'Afghani et al. [43]) links professionalization to depoliticizing the CBO. They argue that "(i)n terms of professionalization, it would be ideal if the technical apparatus is insulated from local politics ..." This would imply that "the head of the village should not be in a management position but in the supervisory board, to prevent this conflict within the CBO daily operation" [43]. However, the eight HIPPAMS studied in this article suggest that an important explanation of the commercial success of these organizations is actually the embedding of the CBO's operations in existing socio-political institutions. This is done through the appointment of the village leadership as management of the HIPPAMs or using the profits from operations to fund village development in the form of roads or schools. Contrary to the argument that water providers should operate at arm's length of the political domain [11,43]), it is actually the politicization of the HIPPAM that allows it to achieve high billing-collection rates and reduce costs. This modifies the model of commercialization and how it is practiced. The HIPPAMs are able to balance their revenue generating capacity with their cost structure only through the use of 'not professional' socially-embedded institutions.

Furthermore, the policy model of commercialization suggests that the water provider should charge tariffs that reflect the actual cost of water service provision. In this ideal, it is argued that cost-recovery is a necessity in order to expand services. 'Appropriate' tariffs regimes are viewed as an important element in expanding safe water services to the unserved [8,44-46]. The emphasis remains on the revenue generation, on charging the 'right' price for water. This ideal of commercialization, thus, does not consider equity implications of charging for water as an issue "but rather argues that 'correct' pricing of water services can concurrently increase both efficiency and equity" [45,47]. In the interpretation of the HIPPAMs of commercialization of their services, however, this CBOs do not focus on charging the right tariff exclusively, but most of their efforts are concentrated on the minimization of costs. The HIPPAMs economize on treatment costs, depend on voluntary labor, and opt to exclude households from their network as they are deemed too expensive to service. As such, the practice of commercialization as implemented by the HIPPAMs is also very much about tinkering with the levels of service provided to consumers in order to keep costs (and thus also tariffs) relatively low. Implementing commercialization may thus not necessarily lead to better services and access for all, rather present incentives to organizations that are expected to function financially independent to do the opposite.

\section{Conclusions}

The topic of commercialization in the water services sector has attracted considerable scholarly attention in the past decades. The resulting literature streams have both promoted and critiqued commercialization. Those in favor of commercialization argue that the adoption of commercial principles such as cost recovery and autonomy lead to financial sustainability and is a pre-condition for achieving universal service coverage [10,48]. Those opposing commercialization argue that it prioritizes efficiency at the expense of equity $[12,19,44,49]$. The actual practice of commercialization-how it translates in the day-to-day decisions of these operators-has, however, received much less scholarly attention than the discussions in favor or against the concept of commercialization. In this article, we have tried to expand on the idea that during implementation of policy models implementers may adjust and modify the policy ideal. This approach reveals, using the case of CBOs in the Lamongan Regency as a case study, that commercialization principles are able to co-exist in at least two forms. On the one hand, a model of commercialization exists that is promoted by the World Bank, donors and the Indonesian government. This model, presented in global policy domains, is based on the assumption that when and if viable services are achieved it must be because the operators have adhered 
to the exact implementation of principles as prescribed in the reform policy [39]. At the same time, commercialization as practiced on a daily basis by the HIPPAMs deviates and re-interprets these principles, to the point of questioning their very same essence and meaning. This shows in turn two things: one, commercial viability can be implemented through the application of not typically commercial practices, and two, implementation can develop in parallel to the policy model without having to argue against it, which facilitates the implementation but it provides a skewed image of the applicability and usefulness of the policy principles.

For these reasons, we believe it is essential to do away with a uniform language on commercialization, which only highlights the broad policy principles of commercialization and that assumes that the achieved results can be directly linked to the adherence to some ideal commercial principles and practices, prescribed elsewhere. It is only through the re-interpretation of these principles, embedded within the specific social and political context in which the HIPPAMs operate, that these organizations manage to be commercially viable. According to us, this points to a much richer reality of how commercialization is actually practiced. Also, it helps contribute differently to the discussion on implementation studies elaborating in more detail the conclusion that all implementation is 'context specific'.

We would find it useful to explore in more detail the practices of commercialization, and believe that investigating these practices will lead to a richer vocabulary that helps understand different manifestations and interpretations of commercialization. This would be helpful for two reasons. First, it would make it possible to refer to commercialization in non-totalizing ways. Currently, commercialization is seen as the end-goal rather than as a means to provide adequate and safe drinking water to all consumers. What the case of the HIPPAMs shows is that there are multiple ways of embodying commercialization. There are apparently ways of providing sustainable services without necessarily complying with all of the principles of commercialization. This indicates that there are multiple ways of both interpreting commercial sustainability and multiple ways of pursuing such sustainability. Second, enriching the language to talk about commercialization allows the process by which operators achieve desired results of providing services to be discussed in greater detail, rather than equating practices to a type of operator. This article shows that it is not sufficient to refer to private operators, commercialized CBOs to understand how these operators are working, and how their decisions are informed, in practice. Their choices are not always, and not necessarily, informed by the type of organization or they assumed identity. Allowing for this discussion would perhaps help open up the discussion - with empirical detail at hand-about the desirability of the incentives commercialization reforms creates for the operator (beyond its assumed private sector or community inclination).

Enriching the language to talk about commercialization is also necessary to promote learning across different policy domains. Although the global policy domain and the domain of everyday operations are connected, very little learning takes place between the everyday practices and the global and national policy domains. The actual practices in the everyday do not appear to inform the design of the models employed at the national and international policy domains. Arguably, and as long as there is no space to discuss implementation as not a deviation of the policy ideal, but as a continuation of the policy process, there is little learning required for these spaces to stop existing in parallel. With an enrichment of the language to reflect what is already happening on the ground we may be able to devise more effective relationships between operators and the institutional environment in which they operate. Instead of being commercial or not, financially sustainable or not, a more rich vocabulary would help describe different degrees and forms of commercialization, and perhaps lead to a more honest discussion about what and why operators do what they do and what impacts those choices have on the services the final user receives (or not).

Author Contributions: M.T. designed and directed the project, contributed to the analysis of the data and conceived of the presented ideas. R.A.S. independently collected raw data, adjusted the project design in the field as necessary and in consultation with M.T. and participated in the analysis of the data. K.S. supervised the work and contributed to the theoretical framework. M.T. and K.S. contributed equally to the writing of the manuscript. 
Funding: This research was developed as the partial completion of M.T. PhD dissertation and R.S' MSc thesis. M.T. research has been partially funded by DUPC 2 (Programmatic Cooperation between DGIS - Ministry of Foreign Affairs Netherlands and IHE Delft), and R.S. received a scholarship from NUFFIC (Dutch organization for internationalization in education) to complete his MSc at IHE Delft 2015-2017. The research conducted for this article was partially funded by NUFFIC.

Conflicts of Interest: The authors declare no conflict of interest.

\section{References}

1. Bakker, K. Hegemony does not imply homogeneity: Thoughts on the marketization and privatization of water. In Contemporary Water Governance in the Global South: Scarcity, Marketization and Participation; Harris, L., Goldin, J., Sneddon, C., Eds.; Routledge: New York, NY, USA, 2013.

2. Brenner, N.; Peck, J.; Theodore, N. Variegated neoliberalization: Geographies, modalities, pathways. Glob. Netw. 2010, 10, 182-222. [CrossRef]

3. Yates, J.S.; Harris, L.M. Hybrid regulatory landscapes: The human right to water, variegated neoliberal water governance, and policy transfer in Cape Town, South Africa, and Accra, Ghana. World Dev. 2018, 110, 75-87. [CrossRef]

4. Maynard-Moody, S.; Herbert, A.W. Beyond Implementation: Developing an Institutional Theory of Administrative Policy Making. Public Adm. Rev. 1989, 49, 137. [CrossRef]

5. Stone, D. Transfer and translation of policy. Policy Studies. 2012, 6, 483-499. [CrossRef]

6. Berman, P. The Study of Macro and Micro Implementation of Social Policy; Rand Paper Series. Available online: https://www.rand.org/pubs/papers/P6071.html (accessed on 17 May 2019).

7. Mukhtarov, F. Rethinking the travel of ideas: policy translation in the water sector. Policy and Politics 2014, 42, 71-88. [CrossRef]

8. Franceys, R. GATS, 'privatization' and institutional development for urban water provision: Future postponed'? Prog. Dev. Stud. 2008, 8, 45-58. [CrossRef]

9. Marin, P. Public-Private Partnerships for Urban Water Utilities: A Review of Experiences in Developing Countries; World Bank: Washington, DC, USA, 2009.

10. Gerlach, E.; Franceys, R. Regulating Water Services for All in Developing Economies. World Dev. 2010, 38, 1229-1240. [CrossRef]

11. Baietti, A.; Kingdom, W.; Ginneken, M. Characteristics of Well-Performing Public Water Utilities; World Bank: Washington, DC, USA, 2006.

12. McInnes, P. Entrenching inequalities: The impact of corporatization on water injustices in Pretoria. In The Age of Commodity: Water Privatization in Southern Africa; Ruiters, G., Ed.; Earthscan: London, UK, 2005.

13. Tyman, N.; Kingdom, B. A Water Scorecard: Setting Performance Targets for Water Utilities; April 2002: Note Number 242; World Bank: Washington, DC, USA, 2002.

14. Kitonsa, W.; Schwartz, K. Commercialisation and centralisation in the Ugandan and Zambian water sector. Int. J. Water 2012, 6, 176-194. [CrossRef]

15. Bakker, K. The "Commons" Versus the "Commodity": Alter-globalization, Anti-privatization and the Human Right to Water in the Global South. Antipode 2007, 39, 430-455. [CrossRef]

16. Boyne, G.A. Public and Private Management: What's the Difference? J. Manag. Stud. 2002, 39, 97-122. [CrossRef]

17. Furlong, K. Water and the entrepreneurial city: The territorial expansion of public utility companies from Colombia and the Netherlands. Geoforum 2015, 58, 195-207. [CrossRef]

18. Hughes, O. Public Management and Administration: An Introduction, 3rd ed.; Palgrave MacMillan: New York, NY, USA, 2003.

19. Marson, M.; Savin, I. Ensuring Sustainable Access to Drinking Water in Sub Saharan Africa: Conflict between Financial and Social Objectives. World Dev. 2015, 76, 26-39. [CrossRef]

20. UN GA (General Assembly). New Delhi Statement - Some for all rather than more for some. A/C.2/45/3. Report of the Economic and Social Council; Annex, 2-7; UN GA (General Assembly): New York, NY, USA, 1990.

21. WMO. Dublin Statement on Water and Sustainable Development. International Conference on Water and Environment (ICWE). Dublin, Ireland, January 1992. Available online: http://www.wmo.int/pages/prog/ hwrp/documents/english/icwedece.html (accessed on 20 September 2019). 
22. IRC. Community Management Today: The role of communities in the management of improved water supply systems. Occasional Paper 20; International Water and Sanitation Center: The Hague, The Netherlands, 1993.

23. Feachem, R. Community Participation in Appropriate Water Supply and Sanitation technologies: The Mythology for the Decade, Proceedings of the Royal Society of London. Ser. B Biol. Sci. 1980, 209, 15-29.

24. Collignon, B.; Vézina, M. Independent Water and Sanitation Providers in African Cities; Water and Sanitation Program: Washington, DC, USA, 2001.

25. Moriarty, P.; Smits, S.; Butterworth, J.; Franceys, R. Trends in rural water supply: Towards a service delivery approach. Water Altern. 2013, 6, 329-349.

26. Cornwall, A.; Gaventa, J. From Users and Choosers to Makers and Shapers: Repositioning Participation in Social Policy; IDS Working Paper 127; John Wiley and Sons: Brighton, UK, 2001; Available online: https: //opendocs.ids.ac.uk/opendocs/bitstream/handle/123456789/3473/Wp127.pdf (accessed on 1 May 2019).

27. Lockwood, H.; Le Gouais, A. Professionalising Community-Based Management for Rural Water Services; Triple-S Briefing Note; 2015. Available online: https:/www.ircwash.org/sites/default/files/084-201502triples_bn01defweb_1_0.pdf (accessed on 20 April 2019).

28. Lockwood, H.; Bakalian, A.; Wakeman, W. Assessing Sustainability in Rural Water Supply: The Role of Follow-up Support to Communities; World Bank: Washington, DC, USA, 2003.

29. Carter, R.C.; Tyrrel, S.F.; Howsam, P. The Impact and Sustainability of Community Water Supply and Sanitation Programmes in Developing Countries. Water Environ. J. 1999, 13, 292-296. [CrossRef]

30. Harvey, P.; Reed, R. Community-managed water supplies in Africa: Sustainable or dispensable? Community Dev. J. 2007, 42, 365-378. [CrossRef]

31. Katz, T.; Sara, J. Making Rural Water Supply Sustainable: Recommendations from a Global Study; Water and Sanitation Program; UNDP-World Bank: Washington, DC, USA, 1997.

32. Whaley, L.; Cleaver, F. Can 'functionality' save the community management model of rural water supply? Water Resour. Rural. Dev. 2017, 9, 56-66. [CrossRef]

33. Asian Development Bank. Indonesia: Water Supply and Sanitation Sector Assessment, Strategy, and Road Map; Asian Development Bank: Manila, Philippines, 2012.

34. World Bank. Sustainability Assessment of Rural Water Service Delivery Models: Findings of a Multi-Country Review; World Bank: Washington, DC, USA, 2017.

35. Setiawan, D. Upgrading Community-Based Pipe Water Services with Private Sector Support; Water and Sanitation Program: Washington, DC, USA, 2011.

36. Surya, R. Commercialization of Community based Water Service Provider: Case of Lamongan Regency Water Service Provision. Master's Thesis, WM-WSM 17-26. IHE-Delft, Delft, The Netherlands, 2017.

37. Hadipuro, W. Indonesia's water supply regulatory framework: Between commercialisation and public service? Water Altern. 2010, 3, 475-491.

38. Badan Perencanaan Pembangunan Nasional (BAPPENAS). National Policy: Development of Community-Based Water Supply and Environmental Sanitation; Badan Perencanaan Pembangunan Nasional (National Development Planning Agency): Jakarta, Indonesia, 2003.

39. Water and Sanitation Program (WSP). The Hard Way to the High Road: Transition of Community-Based Water Groups to Professional Services Providers in Indonesia; Learning Note: January 2011; Water and Sanitation Program: Washington, DC, USA, 2011.

40. Water and Sanitation Program (WSP). Water Supply and Sanitation in Indonesia: Turning Finance into Service for the Future; Service Delivery Assessment: May 2015; Water and Sanitation Program: Washington, DC, USA, 2015.

41. Badan Peningkatan Penyelenggaraan Sistem Penyediaan Air Minum (BPPSPAM). Indonesia Water Utility Performance 2015; BPPSPAM: Jakarta, Indonesia, 2015.

42. Hutchings, P.; Chan, M.Y.; Cuadrado, L.; Ezbakhe, F.; Mesa, B.; Tamekawa, C.; Franceys, R. A systematic review of success factors in the community management of rural water supply over the last 30 years. Water Policy 2015, 17, 963-983. [CrossRef]

43. Al'Afghani, M.; Paramita, D.; Avessina, A.V.; Muhajir, M.A.; Heriati, F. The Role of Regulatory Frameworks in Ensuring the Sustainability of Community-Based Water and Sanitation; Center for Regulation Policy and Governance: Bogor, Indonesia, 2015.

44. Jaglin, S. The right to water versus cost recovery: Participation, urban water supply and the poor in sub-Saharan Africa. Environ. Urban. 2002, 14, 231-245. [CrossRef] 
45. Rusca, M.; Schwartz, K. From passive recipient to empowered client? The changing role of water consumers. Environ. Eng. Manag. J. 2018, 11, 991-997. [CrossRef]

46. Winpenny, J.T. Managing Water as an Economic Resource; Routledge: London, UK; New York, UK, 1994.

47. Rogers, P.; de Silva, R.; Bhatia, R. Water is an economic good: How to use prices to promote equity, efficiency, and sustainability. Water Policy 2002, 4, 1-17. [CrossRef]

48. Kessides, I. Reforming Infrastructure Privatization, Regulation, and Competition; World Bank: Washington, DC, USA, 2004.

49. McDonald, D. Public Ambiguity and the Multiple Meanings of Corporatization. In Rethinking Corporatization and Public Services in the Global South; Zed Books: London, UK, 2014.

(C) 2019 by the authors. Licensee MDPI, Basel, Switzerland. This article is an open access article distributed under the terms and conditions of the Creative Commons Attribution (CC BY) license (http://creativecommons.org/licenses/by/4.0/). 